\title{
Biological mode of action of Clostridium difficile toxin A: a novel enterotoxin
}

\author{
T. J. MITCHELL, J. M. KETLEY, D. W. BURDON*, D. C. A. CANDYt and J. STEPHEN \\ Department of Microbiology, University of Birmingham, P.O. Box 363, Birmingham B15 2TT, "The General \\ Hospital, Steelhouse Lane, Birmingham B4 6NH and tInstitute of Child Health, Francis Road, Birmingham \\ B16 8ET
}

\begin{abstract}
Summary. Antibody neutralisation and toxin A elution experiments showed that toxin A uptake from rabbit intestinal lumen was a continuous process. The kinetics of the ileal and colonic responses were significantly different; a much longer incubation (4 h) with toxin was required for colon, compared with $45 \mathrm{~min}$ for the ileum, to induce fluid accumulation at $12 \mathrm{~h}$. Fluid secretion was induced only when toxin had gained access to deeper tissues, probably achieved by several toxin uptake-tissue damage cycles. Toxin A induced haemorrhage in both ileal and colonic tissues. In ileum, the villus architecture was severely damaged and this gave rise to protein-rich bloody luminal fluid. In the colon, although colonocytes were removed, the basement membrane remained intact; this resulted in a tissue-localised haemorrhage and a protein-low watery ultrafiltered luminal fluid. Toxin $A$ is thus a novel type of histotoxic enterotoxin.
\end{abstract}

\section{Introduction}

Mitchell et al. (1986) previously showed that purified Clostridium difficile toxin A caused a watery secretion associated with tissue disruption in ligated rabbit colonic loops. In contrast it caused a bloody proteinaceous secretion in ligated rabbit ileal loops. The aim of the present work was to investigate the basis of the differential response to toxin $A$ of rabbit ileum and colon. No evidence has been found for a classical biochemical secretory diarrhoea (Mitchell et al., 1987).

\section{Materials and methods}

\section{Animals}

Male New Zealand white rabbits $(2-2.5 \mathrm{~kg}$; Regal Rabbits, Surrey) were used in all studies. Animals were starved overnight, but were given water ad libitum.

\section{Toxin production and purification}

This was performed as described by Mitchell et al. (1987).

Received 12 May 1986; revised version accepted 23 Jul. 1986. $\ddagger$ Correspondence should be sent to Dr J. Stephen, Department of Microbiology, University of Birmingham, Birmingham BT15 2TT.

\section{Antitoxin}

Antitoxin A was prepared as described by Redmond et al. (1985).

\section{ELISA procedure}

The test used to quantify toxin A had a limit of detection of $5 \mathrm{ng} / \mathrm{ml}$ and was performed as described by Redmond et al. (1985).

\section{Rabbit ileal and colonic loops}

Ileal and colonic loops were constructed as previously described (Mitchell et al., 1986), with the following modifications. The colon was ligated approximately $25 \mathrm{~cm}$ distal to the caecum-colon junction; $20 \mathrm{ml}$ of saline was introduced into the lumen at the ligation point and was washed back up the colon and into the caecum. This was repeated with a further two $20-\mathrm{ml}$ volumes of saline and the colon then ligated at the caecum-colon junction.

\section{Toxin elution experiments}

Animals were anaesthetised with Saffan $(18 \mathrm{mg} / \mathrm{kg}$; Glaxovet, Willington Medical, Shrewsbury). A maximum of eight ileal loops were constructed in each of four rabbits. The first of the loops was inoculated with saline as a negative control and the last provided a positive control (q.v.). Each of the remaining loops received an injection of $50 \mu \mathrm{g}$ of toxin $\mathrm{A}$. The toxin-treated loops were washed out after $0,15,30$ and $60 \mathrm{~min}$ in two rabbits and hourly from 2 to $6 \mathrm{~h}$ in another two. The loops 
were cannulated at one end by introducing $1-\mathrm{cm}$ bore plastic tubing through an incision in the gut wall made near the ligation; $10 \mathrm{ml}$ of saline was introduced into the opposite end of the loop with a syringe, and was flushed out through the cannula. This process was repeated with a further four $10-\mathrm{ml}$ volumes of saline. This procedure was sufficient to remove all unbound toxin $\mathrm{A}$ from the loops; the final two washes contained levels of toxin A that were undetectable by ELISA, i.e., $<5 \mathrm{ng} / \mathrm{ml}$. All washings were retained for analysis of toxin levels by ELISA. The cannula was removed from the loop and the cannulation point isolated from the loop with a fresh ligature. Negative control loops were subjected to the same washing procedure. After all loops had been incubated with toxin, the ileum was replaced into the abdomen and the incision closed. The eighth loop served as a positive control in which $10 \mu \mathrm{g}$ of toxin $\mathrm{A}$ was inoculated at time 0 and left for $12 \mathrm{~h}$. After $12 \mathrm{~h}$ loops were examined and fluid accumulation ratios $(\mathrm{ml} / \mathrm{cm})$ calculated.

The amount of toxin bound per loop was calculated as: (total toxin added) minus (total toxin recovered).

For colonic loops, the experimental protocol used was the same as that for ileum except that a maximum of three time points were examined in each of eight rabbits, because the length of colon available for use was limited by anatomical considerations.

Mean values at all time points were calculated from data from two rabbits.

\section{Antibody rescue experiments}

These were performed in a similar way to the loop washing experiments, but instead of washing toxin out of

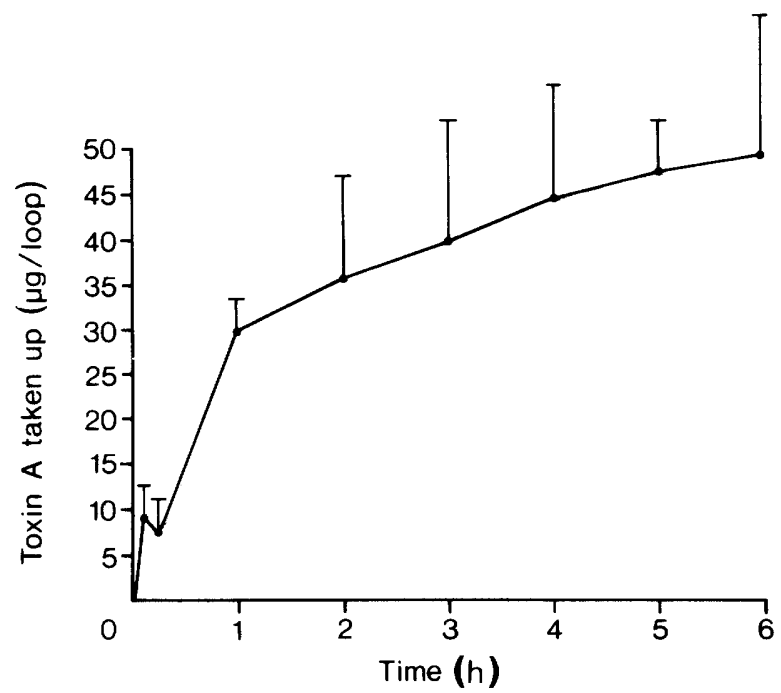

Fig. 1. Kinetics of toxin uptake from ileal loops. Loops were inoculated with $50 \mu \mathrm{g}$ of purified toxin A and incubated for various periods. Unbound toxin was washed from the loops and measured by ELISA. The amount of toxin bound and absorbed by the loop was calculated from the difference between the amount of toxin added and that recovered. Data are the mean of two experiments and error bars represent the SD of the mean.
Table I. Effect on fluid secretion of varying the time of exposure of ileal tissue to $50 \mu \mathrm{g}$ of purified toxin A. All times of exposure were sufficient for enough toxin to bind to induce histological changes at $12 \mathrm{~h}$. Data are from two experiments and are expressed as means \pm SD

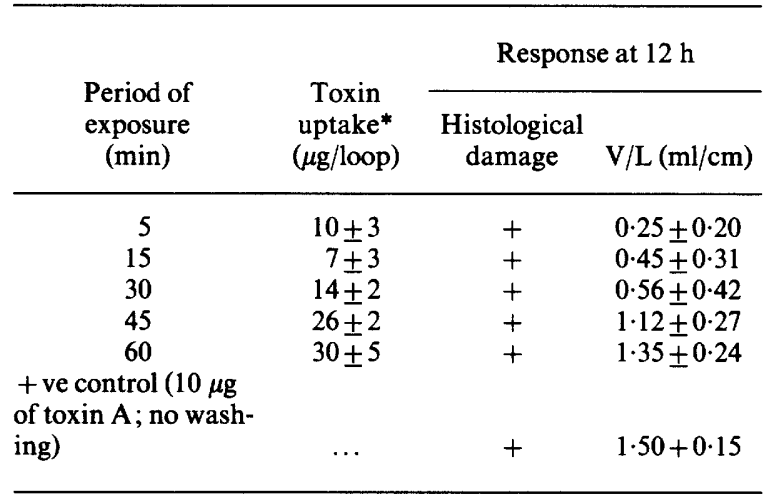

$\mathrm{V} / \mathrm{L}=$ Volume in $\mathrm{ml}$ per $\mathrm{cm}$ length of ligated loop.

* Data from fig. 1.

loops, $1 \mathrm{ml}$ of antitoxin $\mathrm{A}$ (containing 5 times the amount of antibody needed to neutralise the dose of toxin A added to the loop) was added to the loops. For ileal studies, data for time points $0,15,30$ and $45 \mathrm{~min}$ were obtained from one rabbit and for 1, 2 and $3 \mathrm{~h}$ from a second rabbit. For colonic studies, three rabbits were used; one for 0,5 and $15 \mathrm{~min}$ incubation, one for 30,45 and $60 \mathrm{~min}$ and a third for 2,3 and $4 \mathrm{~h}$.

All experiments were repeated and means calculated from the data from two experiments.

\section{Histological studies}

Segments of intestinal loops were fixed in formaldehyde $(4 \%$ in saline). The tissues were embedded in paraffin wax, sectioned and stained with haematoxylin and eosin or toluidine blue for examination by light microscopy.

\section{Protein determinations}

These were done with the BioRad protein assay kit (BioRad Laboratories Ltd., Watford).

\section{Sodium, potassium and chloride determinations}

Chloride levels in loop contents were measured with an EEL 920 chloride meter; sodium and potassium levels were determined with a Corning 460 flame photometer.

\section{Results}

\section{Toxin elution experiments}

Ileum. The kinetics of toxin A uptake from ileal loops are shown in fig. 1 . In this experiment, all 

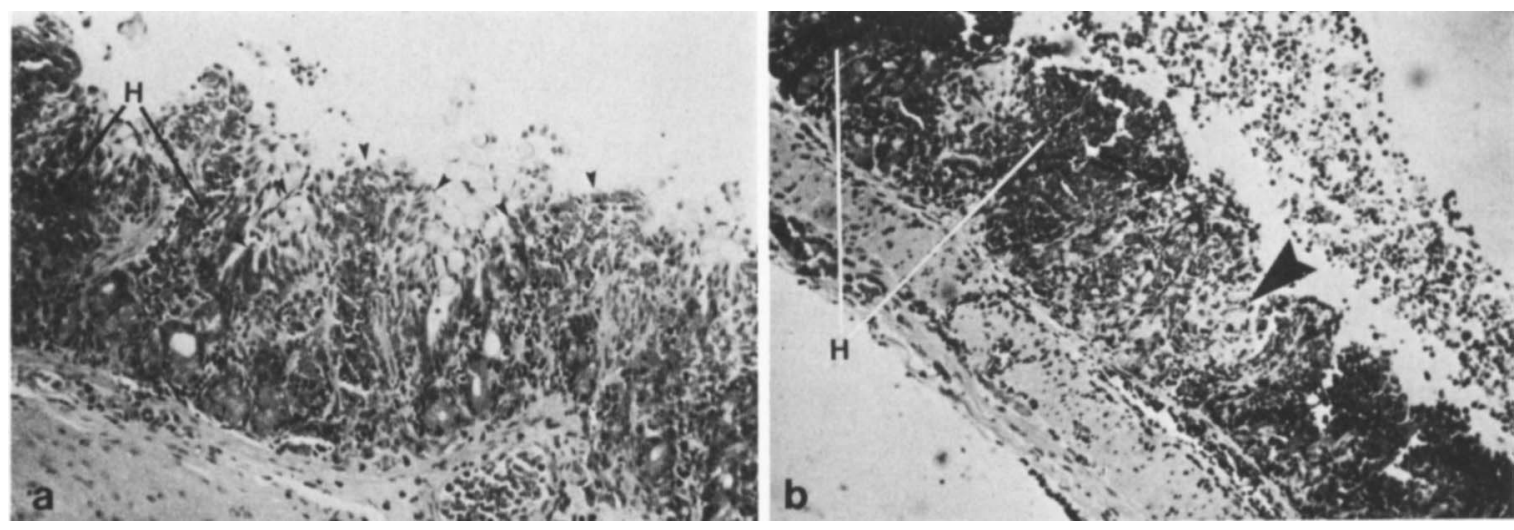

Fig. 2. Histological effect of $10 \mu \mathrm{g}$ of toxin A on rabbit ileum after incubation for $12 \mathrm{~h}$. (a) $10 \mu \mathrm{g}$ of toxin A associated with tissue by exposure to $50 \mu \mathrm{g}$ toxin A for $5 \mathrm{~min}$ then removal of unbound toxin by washing; no free luminal toxin after $5 \mathrm{~min}$. Damage confined mainly to the tips of the villi, some haemorrhage $(\mathrm{H})$ which remains contained within the villi (periphery of villi illustrated by small arrows). (b) $10 \mu \mathrm{g}$ of toxin A inoculated into and left in lumen. Tissue necrosis as deep as the muscle layers in some areas (large arrow) with gross haemorrhage. (Haematoxylin and eosin; $\times 150$ original magnification). Histological damage is more extensive in (b) than in (a).

loops were challenged with a $50-\mu \mathrm{g}$ dose of toxin A inoculated into each of them. The binding of toxin A was rapid; $10 \mu \mathrm{g}$ of toxin was associated with the tissue after incubation for $5 \mathrm{~min}$. Toxin uptake was a continuous process until all toxin had been absorbed by approximately $6 \mathrm{~h}$. The biological response to toxin which had been ad- or absorbed by tissue in this series of experiments (table I) was unexpectedly different from the response of tissue to an equivalent amount of toxin $\mathrm{A}$ inoculated into and simply left in the ileal lumen. After all periods of exposure sufficient toxin $\mathrm{A}$ had been bound to induce histological changes by $12 \mathrm{~h}$. As stated, exposure of tissue to $50 \mu \mathrm{g}$ of toxin for $5 \mathrm{~min}$ caused $10 \mu \mathrm{g}$ to be associated with the tissue. If at this point the remaining free toxin was washed out of the loop, some histological damage was apparent in tissue sampled from these loops at $12 \mathrm{~h}$ (fig. 2a) but no fluid accumulation had occurred. In marked contrast, the damage induced by $10 \mu \mathrm{g}$ inoculated into the intestinal lumen and left without washing for $12 \mathrm{~h}$ was greater (fig. 2b) and fluid accumulation was induced.

If toxin A was delivered directly into an ileal loop as a bolus of $50 \mu \mathrm{g}$ and allowed to act for 45 min before washing, fluid accumulation was induced by $12 \mathrm{~h}$ (table I). Approximately $30 \mu \mathrm{g}$ of the added $50 \mu \mathrm{g}$ of toxin $\mathrm{A}$ had been taken up by this time (table I). Titration studies (Mitchell et al., 1986) had previously indicated that as little as $3 \mu \mathrm{g}$ of toxin A inoculated into the lumen of $6-\mathrm{cm}$ ileal loops can provoke fluid accumulation by $12 \mathrm{~h} ; 3 \mu \mathrm{g}$ of toxin $\mathrm{A}$ was associated with the tissue by $<5$ min in these toxin uptake experiments, but did not induce fluid accumulation at $12 \mathrm{~h}$. These data are, at first sight, difficult to interpret and are considered further in the discussion.

Colon. Toxin A uptake from the colon was slower than from ileum (fig. 3). After exposure for $5 \mathrm{~min}$, toxin recovery was $100 \%$ from colonic loops and this indicates that no toxin had bound to the tissue. Small amounts of toxin were bound at times up to $45 \mathrm{~min}$, after which there was a rapid uptake of toxin A (fig. 3) which was complete by 5 h. Exposure

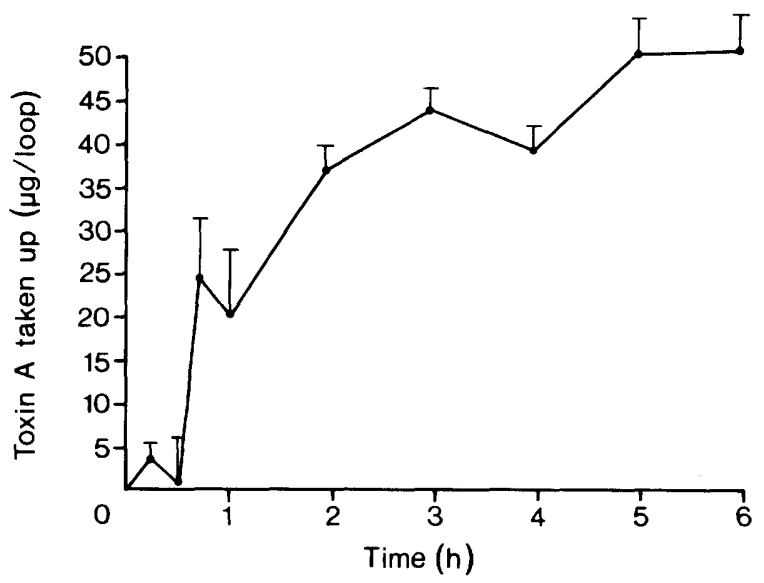

Fig. 3. Kinetics of toxin uptake from colonic loops. Loops were inoculated with $50 \mu \mathrm{g}$ of purified toxin A and incubated for various periods. Unbound toxin was washed from the loops and measured by ELISA. The amount of toxin bound and absorbed by the loop was calculated from the difference between the amount of toxin added and that recovered. Data are the mean of two experiments and error bars represent the SD of the mean. 
of colon to $50 \mu \mathrm{g}$ of toxin $\mathrm{A}$ for $5 \mathrm{~min}$, followed by washing, did not induce a biological response at $12 \mathrm{~h}$. At all time points after $5 \mathrm{~min}$, enough toxin $\mathrm{A}$ was bound by colonic tissue to induce histological changes at $12 \mathrm{~h}$. However, in a manner similar to that seen in ileum, histological changes induced by a given amount of toxin $\mathrm{A}$, bound to the tissue (with unbound toxin removed by washing) were less than those induced by an amount of toxin (equivalent to that bound) injected and left within the lumen. It was necessary to expose colonic tissue to $50 \mu \mathrm{g}$ of toxin $\mathrm{A}$ for at least $3 \mathrm{~h}$ to allow uptake of sufficient toxin $A$ to induce fluid secretion at $12 \mathrm{~h}$ (table II).

\section{Antibody rescue}

Ileum. The effect of adding antitoxin A to toxin A-treated ileal loops after various periods of incubation is shown in table III; we could identify three periods as far as fluid accumulation is concerned: 1. Addition of antitoxin A at $0-45 \mathrm{~min}$ completely prevented fluid accumulation at $12 \mathrm{~h}$. Our studies had already shown that sufficient toxin A was associated with the tissue by $45 \mathrm{~min}$ to induce fluid accumulation at $12 \mathrm{~h}$. 2. Addition of antitoxin $\mathrm{A}$ between $45 \mathrm{~min}$ and $3 \mathrm{~h}$ significantly reduced (but did not abolish) the fluid accumulation seen at $12 \mathrm{~h}$. 3 . Addition of antitoxin later than $3 \mathrm{~h}$ had little effect.

Histological examination showed that tissue damage could be completely prevented if antitoxin A was added to the loop up to, but not beyond, 5 min of the addition of toxin $A$; this suggests that all toxin $A$ is still external to the cells and accessible to neutralising antibody. Addition of antitoxin A after $5 \mathrm{~min}$ led to increasing tissue damage observed at $12 \mathrm{~h}$; the extent of the damage was proportional to the time of incubation of tissue with toxin A before antibody addition. However, the histological changes at any time of incubation were always less in loops treated with antitoxin than in those from which the toxin was washed out. For example, washing toxin from loops after 5 min resulted in tissue damage at $12 \mathrm{~h}$, whereas addition of antitoxin completely prevented these changes.

Colon. Antibody rescue data from the colon were difficult to interpret. Addition of antitoxin A up to but not beyond $45 \mathrm{~min}$ after toxin A prevented fluid accumulation. Fluid accumulation was not prevented by addition of antitoxin $A$ at $60 \mathrm{~min}$, even though washing of toxin A-treated loops did prevent the response (see table II). Thus, although toxin elution experiments showed that at $60 \mathrm{~min}$ sufficient toxin $\mathrm{A}$ to induce fluid accumulation had not been
Table II. Effect on fluid secretion of varying the time of exposure of colonic tissue to $50 \mu \mathrm{g}$ of purified toxin A. Times of exposure greater than 5 min were sufficient for enough toxin to bind to induce histological changes at $12 \mathrm{~h}$. Data are from two experiments and are expressed as means $\pm \mathrm{SD}$

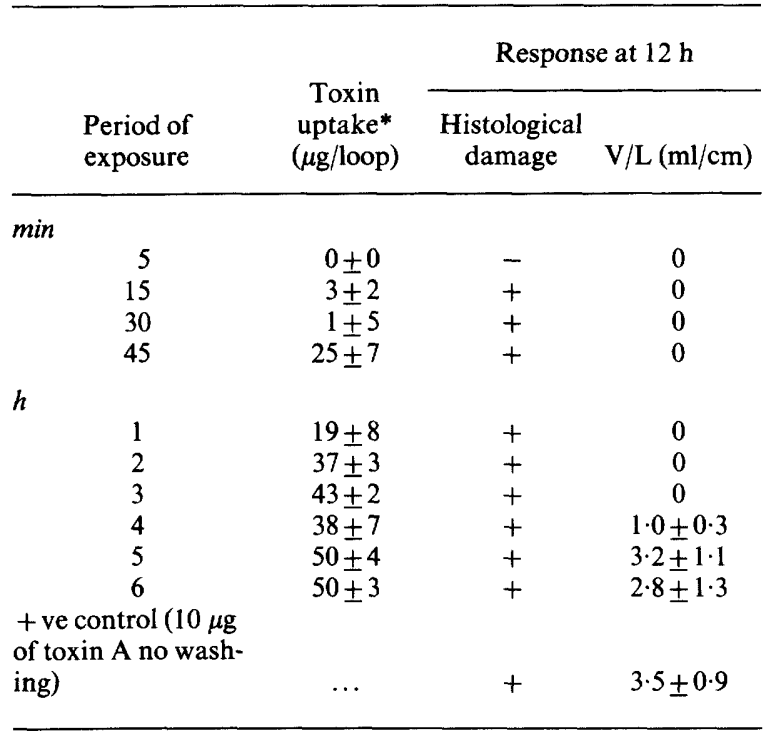

*Data from fig. 3.

Table III. The effect on fluid secretion of addition of antitoxin to toxin A-treated ileal loops after various times of exposure. Addition of antitoxin within 5 min prevented any biological response at $12 \mathrm{~h}$. Times of incubation greater than $5 \mathrm{~min}$ before antitoxin addition resulted in histological damage at $12 \mathrm{~h}$. Data are from two experiments and are expressed as means \pm SD

Period of exposure before addition of anti-

Response at $12 \mathrm{~h}$ toxin

Histological damage $\quad \mathrm{V} / \mathrm{L}(\mathrm{ml} / \mathrm{cm})$

$\min$

$\begin{array}{rll}0 & - & 0 \\ 5 & - & 0 \\ 15 & + & 0 \\ 30 & + & 0 \\ 45 & + & 0\end{array}$

$h$

$\begin{array}{ccc}1 & + & 0 \cdot 2 \pm 0 \cdot 3 \\ 2 & + & 0 \cdot 7 \pm 0 \cdot 2 \\ 3 & + & 1 \cdot 2 \pm 0 \cdot 1 \\ 4 & + & 1 \cdot 3 \pm 0 \cdot 3 \\ 5 & + & 1 \cdot 4 \pm 0 \cdot 2 \\ 6 & + & 1 \cdot 6 \pm 0 \cdot 4 \\ \begin{array}{ll}\text { + ve control. } 10 \mu \mathrm{g} \\ \text { toxin A. No antitoxin } \\ \text { addition }\end{array} & & \\ \end{array}$


internalised, addition of antitoxin at $60 \mathrm{~min}$ did not prevent fluid accumulation (see Discussion).

\section{Biochemical analyses}

Protein, sodium, potassium and chloride levels in loop contents were measured in two experiments (table IV).

\section{Morphological studies}

Light microscopy. Examination of ileal tissue exposed to $10 \mu \mathrm{g}$ of toxin A in a 6-cm ileal loop for $1 \mathrm{~h}$ revealed that structural changes were restricted to the tips of some villi. The early structural changes appeared to involve tissue layers below the brush border. In control tissues, enterocytes were long columnar cells and were associated with a well defined lamina propria (fig. 4). In tissues exposed to toxin for $1 \mathrm{~h}$, the lamina propria at the tips of some villi was disrupted (fig. 5) and the basement membrane-lamina propria interface was ill-defined. The brush border appeared to be intact in most areas, but occasional areas of degeneration were seen (not shown). In some sections, the endothelial layer of the capillaries had been disrupted and red blood cells were observed free within the lamina propria (fig. 5). Some enterocytes within toxin-treated tissue had lost their normal columnar shape; large spaces were present between these cells (fig. 5). In some areas, the disruption of the lamina propria and the change in shape of the enterocytes could be seen to form a visible channel connecting the disrupted lamina propria to the

Table IV. Electrolyte and protein levels of normal rabbit serum and fluid taken from intestinal loops after incubation for $12 \mathrm{~h}$ with either $10 \mu \mathrm{g}$ of toxin $\mathrm{A}$ or $2.5 \mu \mathrm{g}$ of cholera toxin. Data are expressed as the means of two determinations $\pm \mathrm{SD}$

\begin{tabular}{|c|c|c|c|c|}
\hline \multirow[b]{2}{*}{ Sample } & \multicolumn{3}{|c|}{ Concentration of ion $(\mathrm{mEq} / \mathrm{L})$} & \multirow{2}{*}{$\begin{array}{l}\text { Protein } \\
(\mathrm{mg} / \mathrm{ml})\end{array}$} \\
\hline & $\mathrm{Na}^{+}$ & $\mathrm{Cl}^{+}$ & $\mathbf{K}^{-}$ & \\
\hline $\begin{array}{l}\text { Rabbit serum } \\
\text { Ileal loop fluid }\end{array}$ & $140 \pm 5$ & $80 \pm 7$ & $5 \cdot 0 \pm 0 \cdot 5$ & $60 \pm 18$ \\
\hline & $134 \pm 10$ & $92 \pm 9$ & $3 \cdot 8 \pm 1 \cdot 0$ & $50 \pm 23$ \\
\hline $\begin{array}{l}\text { (Toxin } \mathrm{A} ; 10 \mu \mathrm{g} \text { ) } \\
\text { Ileal loop fluid }\end{array}$ & $145 \pm 12$ & $76 \pm 11$ & $7 \cdot 0 \pm 1 \cdot 6$ & $2 \pm 3$ \\
\hline $\begin{array}{l}\text { (Cholera toxin; } \\
2.5 \mu \mathrm{g})\end{array}$ & $150 \pm 20$ & $83 \pm 8$ & $4 \cdot 9 \pm 1 \cdot 2$ & $6 \pm 5$ \\
\hline
\end{tabular}

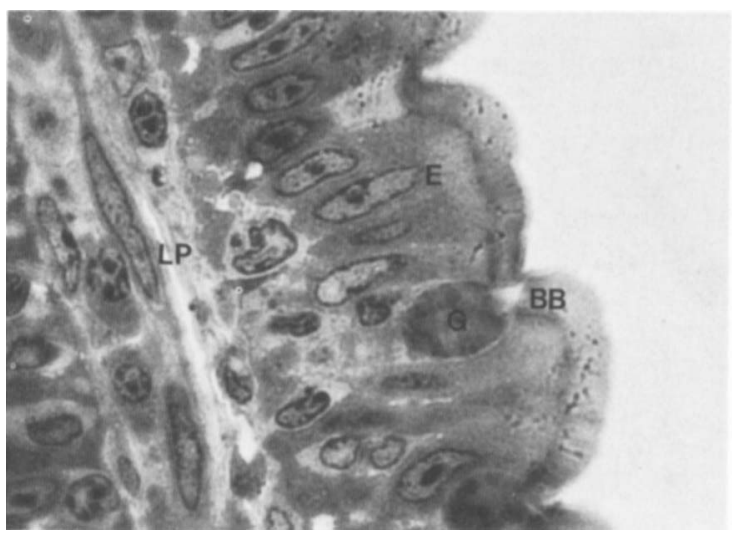

Fig. 4. Control villus. (Toluidine blue; $\times 1500$ original magnification). Normal columnar epithelial cells (E) with brush border (BB). A goblet cell (G) is also visible. The lamina propria (LP) is well defined.

intercellular spaces immediately adjacent to the intestinal lumen.

Examination of tissue taken from colonic loops after exposure for $1 \mathrm{~h}$ to $10 \mu \mathrm{g}$ of toxin A showed changes in the surface epithelium of colon similar to those in ileum. Fig. 6 shows control colon with normal epithelial cells. Toxin A treatment caused the appearance of large intercellular spaces between the epithelial cells (fig. 7) but did not disrupt the lamina propria to the extent that was observed in the ileum. Capillaries in close proximity to the epithelium remained intact and the basement membrane-lamina propria junction remained well defined (fig. 7).

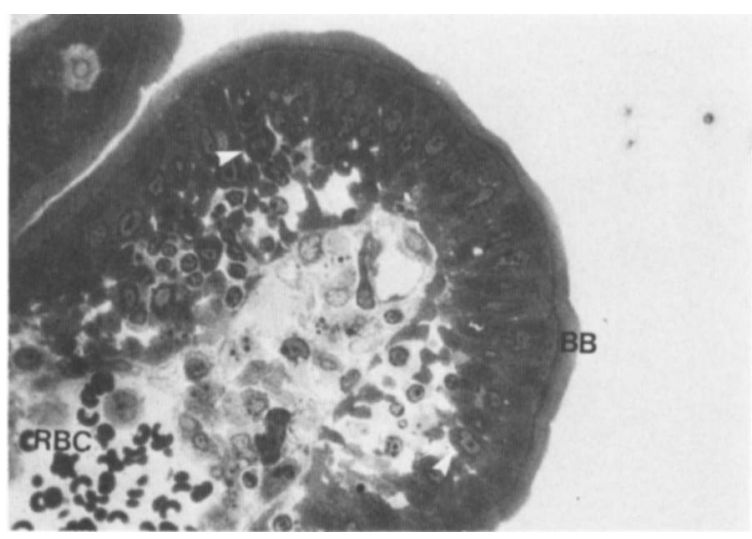

Fig. 5. Villus after exposure of a 6-cm ileal loop to $10 \mu \mathrm{g}$ of purified toxin A for $1 \mathrm{~h}$ (Toluidine blue; $\times 1125$ original magnification). The lamina propria has been disrupted and some epithelial cells can be seen to be rounding up (arrows). The brush border (BB) is intact but a capillary has been disrupted and red blood cells (RBC) can be seen free within the lamina propria. 


\section{Discussion}

Attempts were made to determine the basis for the differential response of rabbit ileum and colon to toxin $\mathrm{A}$ by removing unfixed toxin by washing at varying time points and by antibody rescue experiments. By these means, information was obtained on the kinetics of toxin uptake by the two tissues in relation to early histological changes and fluid secretion.

Uptake experiments showed that exposure of ileum to a high level of toxin A (50 $\mu \mathrm{g}$ in a $6-\mathrm{cm}$ loop) for as little as $5 \mathrm{~min}$ was sufficient for the tissue to bind enough toxin A to induce histological

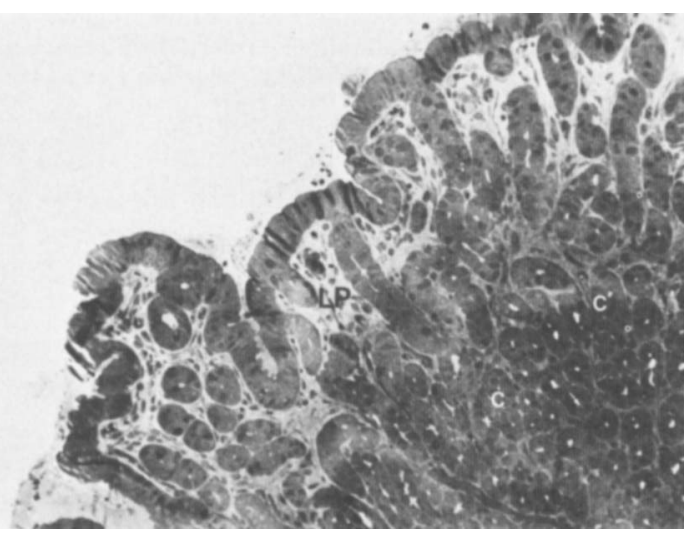

Fig. 6. Control colon (Toluidine blue; $\times 250$ original magnification). Layer of surface epithelium overlying the crypts (C). The lamina propria (LP) lies between the crypts and the surface epithelium.

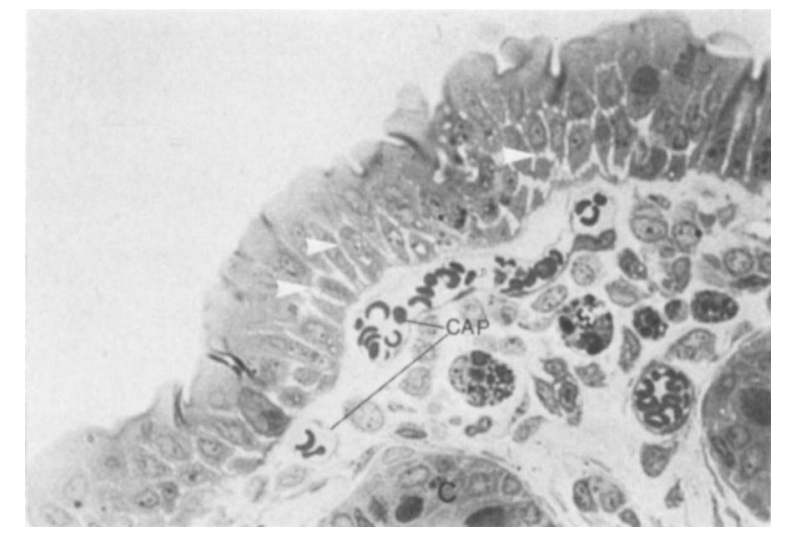

Fig. 7. Colonic tissue taken from a 6-cm colonic loop exposed to $10 \mu \mathrm{g}$ of purified toxin A for $1 \mathrm{~h}$ (Toluidine blue; $\times 1125$ original magnification). Surface epithelial cells have lost their typical shape and large intercellular spaces are present (arrows). Capillaries (CAP) are present within the tissue but have not been disrupted. Cells of the crypts (C) do not appear to be affected by the toxin. changes after a further $12 \mathrm{~h}$ (table I). This indicates that some type of rapid toxin-receptor interaction could be taking place. Sufficient toxin $A$, as judged by washing experiments, was associated with the tissue by $45 \mathrm{~min}$ to cause fluid accumulation and tissue damage at $12 \mathrm{~h}$.

Addition of antitoxin A to ileal loops within 5 min of toxin-A addition prevented the appearance of tissue damage (and fluid secretion) at $12 \mathrm{~h}$. This suggests that for a period of up to $5 \mathrm{~min}$ bound toxin $A$ is on the surface of the enterocytes and still accessible to neutralising antitoxin. Addition of antitoxin A to toxin A-treated ileal loops for up to $45 \mathrm{~min}$ inhibited fluid secretion and diminished (but did not abolish) the amount of tissue damage seen when the loops were examined at $12 \mathrm{~h}$. This suggests that only a portion of the "fluid-inducing dose" of toxin A had been internalised by $45 \mathrm{~min}$, because a portion of the toxin was still accessible to neutralising antitoxin. Addition of antitoxin $\mathrm{A}$ at all times up to $3 \mathrm{~h}$ reduced the extent of tissue damage and secretion seen at $12 \mathrm{~h}$, indicating that toxin internalisation is a continuous process. These results suggest that toxin is being continuously bound, taken up, masked or inactivated, or both, by cells within the ileal mucosa. In the process, fresh susceptible cells or fresh receptors for the toxin are exposed. This progressive uptake continues until the toxin has reached deeper tissue layers (presumably endothelial cells) to allow leakage of vascular proteins and this is responsible for fluid secretion in the ileum.

Toxin uptake studies also showed that there was a marked difference in the biological effect of a given amount of toxin $\mathrm{A}$ according to whether the toxin was bound to tissue (with the remainder removed) or was inoculated into an ileal loop and left without washing. For example, $10 \mu \mathrm{g}$ of toxin A was associated with ileal tissue after exposure for $5 \mathrm{~min}$ to $50 \mu \mathrm{g}$ of toxin A (fig. 1). When unbound toxin was washed from the loop and the loop incubated in situ for $12 \mathrm{~h}$, the toxin already bound induced some histological changes (fig. 2a) but no fluid secretion. In sharp contrast, inoculation of $10 \mu \mathrm{g}$ of toxin $\mathrm{A}$ into the lumen followed by incubation for $12 \mathrm{~h}$ (without any washing) caused histological changes that were far more severe (fig. 2b) and also caused positive fluid accumulation. A model that explains both the data on antibody neutralisation and "wash-out" experiments is discussed in the following paragraph.

The two key postulates in the hypothesis are that toxin binding is concentration dependent, and that initially bound toxin is either not subsequently released from, or is inactivated by, the cells to 
which it is initially bound. When $10 \mu \mathrm{g}$ of toxin A is injected into the ileum and left in the lumen, only a proportion of the toxin binds to the enterocytes, is internalised, and induces some change eventually leading to histological damage to the mucosa. Such toxin-induced changes in the mucosa lead to further uptake of unbound toxin from the lumen into subepithelial tissues. This uptake into deeper tissues results in interaction of the toxin with capillaries and a leakage of vascular proteins and red blood cells. When $10 \mu \mathrm{g}$ of toxin is rapidly bound by enterocytes (achieved by exposing loops to a high initial concentration, in this case $50 \mu \mathrm{g}$ of toxin A) and free toxin within the loop is removed sufficiently early by washing, enterocyte-associated toxin is either not released from or is inactivated by enterocytes and there is no free toxin left to attack sub-mucosal sites. Only a relatively mild histological response occurs and no fluid accumulation is seen at $12 \mathrm{~h}$.

In the colon, toxin uptake studies revealed that incubation for 5 min was insufficient to bind any toxin A to the colonic mucosa; toxin recovery from these loops was $100 \%$ and no biological response was observed at $12 \mathrm{~h}$. This was an important finding, because an alternative explanation for the apparent discrepancy between the dose-response studies and toxin-binding studies (already discussed above) was that toxin $A$ was lost during the washing procedure rather than being associated with the tissue. The problem of deciding whether toxin had been associated with the tissue or lost during the assay is inherent in the type of toxin-binding assay used; the amount of toxin bound to the tissue is calculated as the difference between the amount of toxin added to the loop and the amount of toxin recovered. (It was necessary to use this type of indirect assay of toxin-A binding, because all attempts to directly label toxin $A$ resulted in inactivation of the toxin.) All the toxin-A inoculum was recovered from these loops; therefore toxin losses due to the washing procedure must have been small since the assay was sufficiently sensitive to detect $5 \mathrm{ng}$ of toxin $\mathrm{A} / \mathrm{ml}$. Small amounts of toxin A were associated with colonic tissue after incubation for 15 and $30 \mathrm{~min}$, and these were sufficient to induce histological changes at $12 \mathrm{~h}$. There was a rapid increase in the amount of toxin A associated with tissue by $45 \mathrm{~min}$, indicating that some early toxin A-induced changes may have allowed further toxin absorption.

It was not possible to determine by antibody neutralisation the proportion of toxin $A$ that had been internalised into cells in the colon, because antibody rescue data were difficult to interpret and apparently contradicted loop washing experiments. It is suggested that toxin A must be protected from antitoxin $\mathrm{A}$ by some mechanism other than internalisation; a possible protective factor is mucus.

Colonic loops exposed to high doses $(50 \mu \mathrm{g})$ of toxin A did not accumulate fluid at $12 \mathrm{~h}$ unless incubated with toxin for at least $4 \mathrm{~h}$ before toxin removal (table II). After incubation for $4 \mathrm{~h}, c .40 \mu \mathrm{g}$ of toxin A had been associated with the tissue of a 6 -cm colonic loop. In control loops, $10 \mu \mathrm{g}$ of toxin A inoculated into the lumen and incubated for $12 \mathrm{~h}$ (without washing) caused gross tissue damage and fluid accumulation. The situation in the colon is therefore qualitatively similar to that seen in the ileum (as discussed above) and a similar model to that described for ileum can be proposed for colon. However, the kinetics of the ileal and colonic responses were significantly different in that a much longer incubation with toxin ( $4 \mathrm{~h}$ compared with $45 \mathrm{~min}$ for ileum) was required to induce fluid accumulation at $12 \mathrm{~h}$ in the colon. This difference suggests that, if fluid accumulation is associated with toxin action on the deeper tissues, the toxin does not gain access to sub-epithelial tissues in the colon as readily as it does in the ileum.

To investigate the possible route of access of toxin to sub-epithelial tissue in the ileum and colon, a light microscopy study was performed on tissue from ileal and colonic loops exposed to $10 \mu \mathrm{g}$ of toxin $\mathrm{A}$ for $1 \mathrm{~h}$. In ileal tissue, the toxin caused a marked disruption of the lamina propria, before any overt changes were visible in the brush border. The changes consisted of disruption of capillaries (fig. 5), a rounding of cells associated with the mucosal epithelium, and a perturbation of the basement membrane-lamina propria interface. In colonic tissue, toxin A induces similar changes in the mucosal epithelium to those seen in the ileum, with the loss of the columnar shape of absorptive cells and the appearance of large intercellular spaces (fig. 7). However, no obvious effects were noted in the underlying tissue at this time $(1 \mathrm{~h})$ of incubation. Capillaries in close proximity to the epithelium were seen to be intact and the basement membrane-lamina propria interface remained well defined (fig. 7). Since structural changes were seen to be confined to the epithelial cell layer in the colon, it is suggested that the toxin may not penetrate as readily to deeper layers in this tissue as it appears to do in the ileum. There are two possible reasons for the different extent of penetration by toxin $A$ into the intestinal epithelium of ileum and colon. First, if toxin enters via a transcellular absorptive pathway, colonocytes may be less efficient at macromolecular absorption than 
ileocytes. Second, if toxin enters the tissue by an intercellular route, the tissue may be less permeable to macromolecules. Colon has been shown to be less permeable than ileum; it excludes horseradish peroxidase to a greater extent (Warshaw et al., 1977). Toxin elution experiments also showed that colonic tissue needed a much longer incubation with toxin than ileal tissue to induce fluid accumulation. These findings are consistent with the postulate that toxin does not gain access to the deeper tissue layers in the colon as readily as it does in the ileum.

We propose that toxin A has differential effects on rabbit ileum and colon due to different uptake patterns for the toxin. In the ileum, surface cells appear to take up the toxin rapidly, resulting in changes that allow access of more toxin from the lumen to the deeper tissue layers. These changes may involve damage to the tight junctions or other permeability barriers, such as the basement membrane, which would lead to increased permeability of the mucosa to macromolecules in general. However, in the colon, access of toxin to the deeper tissue layers took longer than in ileum. This may have been due to occlusion or inactivation, or both, of toxin by mucus, which slowed down the whole process of efficient transport and penetration. Furthermore, the observed difference could be due to the fact that the permeability of the colon to macromolecules generally is inherently lower, and that the effect of the toxin on permeability barriers was less.

All of these possibilities could explain the difference in composition of fluid in ileal and colonic loops (table IV). Damage to capillaries was widespread in the ileum, and less in the colon, perhaps reflecting the relative ease of tissue penetration by the toxin. Plasma proteins that leaked into the lamina propria would pass out through damaged tight junctions (and basement membranes) into the lumen more readily in ileum than colon. In the latter less leaky and less damaged system, a greater degree of residual ultrafiltration capacity would be retained giving rise to the "cholera-like" fluid, a theory supported by the observation of a continuous membrane-like structure overlying intoxicated colon at $12 \mathrm{~h}$ (figs. 8a, b); such a structure was not seen in sections of intoxicated ileal loops. Similar structures have been found in a re-interpretation of our original material: in fig. 6 of the paper by Mitchell et al. (1986) this membranous structure did not reproduce clearly.

In conclusion, we make three points of potential clinical importance. 1 . We have described how C.difficile toxin $\mathrm{A}-\mathrm{a}$ tissue-damaging haemor-

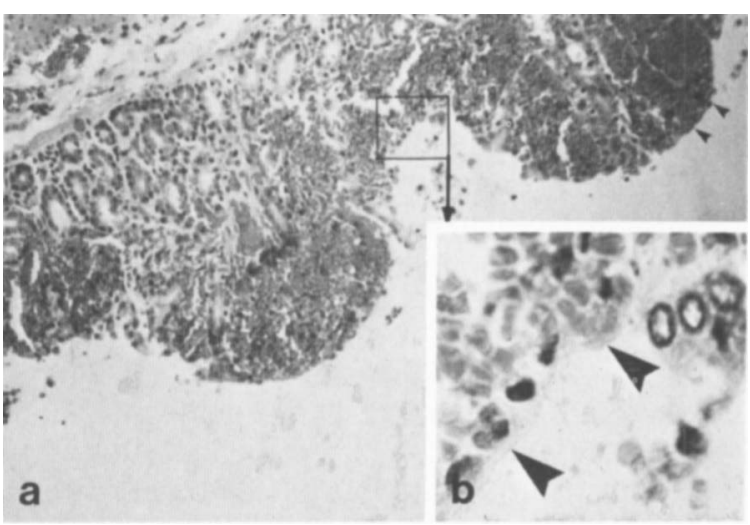

Fig. 8. Colonic tissue taken from a 6-cm colonic loop exposed to $10 \mu \mathrm{g}$ of purified toxin A for $12 \mathrm{~h}$ (Haematoxylin and eosin; $\times 63$ original magnification, a, and $\times 250$ original magnification, b). Note tissue-localised haemorrhage in region below small arrows; red blood cells not released into lumen (a). Note retention of intact membranous structure (large arrows) even in region of greatest disruption of tissue (b) which effectively contains the haemorrhage within the tissue and is postulated to be the ultrafiltration barrier responsible for low protein in colonic luminal fluid.

rhagic toxin-could give rise to the watery diarrhoea seen in pseudomembranous colitis (PMC) if, as would be the case, the toxin were synthesised and released predominantly in the colon. To our knowledge, this is the first time that such a phenomenon has been described for any histotoxic bacterial toxin. It is possible that a third toxin of C.difficile, reported by Banno et al. (1984) and unrelated to toxins A and B, could be responsible for watery fluid secretion, but there are two reasons why we think that this is not probable. First, the test system used by Banno et al. (1984) was the rabbit ileum, which is almost certainly a less relevant model for PMC disease than rabbit colon. Second, in only one of several attempts was the presence of such a toxin demonstrated in our laboratory (T. J. Mitchell, unpublished data). It is, therefore, highly labile (as the original authors state) or it was present in an inactive form in the majority of our preparations, or its activity was masked by the response of the tissue to toxin $A$.

2. It is possible to speculate upon the reason for the comparatively low-volume watery diarrhoea associated with PMC. This could arise from a limited number of foci of $C$.difficile infection within which toxin A is synthesised and where (on the basis of our findings) it would be bound or occluded and from which it would not disseminate widely.

3. Massive colonic involvement (sometimes seen at autopsy) with little or no immediate pre-history 
of diarrhoea could be due to the production (within many close or near confluent foci) of very large quantities of toxin $\mathrm{A}$, the absorption of which would result in rapidly lethal effects as observed in several test species when toxin $A$ is injected parenterally (Arnon et al., 1984).

\section{REFERENCES}

Arnon S S, Mills D C, Day P A, Hendrickson R V, Sullivan N M, Wilkins T D 1984 Rapid death of infant rhesus monkeys injected with Clostridium difficile toxins A and B: physiologic and pathologic basis. Journal of Pediatrics 104: 34- 40 .

Banno Y, Kobayashi T, Kono H, Watanabe K, Ueno K, Nozawa Y 1984 Biochemical characterization and biologic actions of two toxins (D-1 and D-2) from Clostridium difficile. Reviews of Infectious Diseases 6 (Suppl 1): S11-S20.

Mitchell T J et al. 1986 The effect of toxin A and toxin B of Clostridium difficile on rabbit ileum and colon. Gut 27: 7885.

Mitchell T J, Ketley J M, Candy D C A, Burdon D W, Stephen
JS, DWB, and DCAC thank Pfizer Central Research and the Science and Engineering Research Council for CASE studentship to T.J.M., and the Medical Research Council for studentship to J.M.K. We thank Mr J. Farrier, Pfizer Central Research, Kent, for performing the electrolyte assays, and Mrs J. Gem, Microbiology Department, University of Birmingham, for assistance with the histology.

J 1987 The effects of Clostridium difficile crude toxins and purified toxin A on stripped rabbit ileal mucosa in Ussing chambers. Journal of Medical Microbiology 23: 21 1-219.

Redmond S C, Ketley J M, Mitchell T J, Stephen J, Burdon D W, Candy D C A 1985 Detection of Clostridium difficile enterotoxin (toxin A) by ELISA and other techniques. In: Collins C H, Grange $\mathbf{J} \mathbf{M}$ (eds) Isolation and identification of micro-organisms of medical and veterinary importance. (Society for Applied Bacteriology, Technical Series 21) Academic Press, London, pp 237-250.

Warshaw A L, Bellini C A, Walker W A 1977 The intestinal mucosal barrier to intact antigenic protein. Difference between colon and small intestine. American Journal of Surgery 133: 55-58. 